\title{
SALURAN DISTRIBUSI KOMODITI CABAI RAWIT DI PASAR BERSEHATI KOTA MANADO
}

\author{
Heryanto Siahaan \\ Lyndon R. J. Pangemanan \\ Audrey J. M. Maweikere
}

\begin{abstract}
This study aims to find out the distribution channel of Cayenne Chili at Bersehati Market, Manado City. The data used are primary data. Primary data is obtained through a list of questions. Sampling method by purposive sampling and Snowball Sampling method for marketing institution, the sample is obtained based on information from interview to the respondent and traced to the next respondents in chains. The number of respondent is 20 people because it is representative of respondent. The results of this study show that the Distribution Channel that occurs in Bersehati Market consists of 3 distribution channels. Marketing institutions involved include collecting dealers, wholesalers, retailers. Distribution activities in Bersehati Market are activities that start from partners and cooperation between farmers and marketing institutions involved in marketing activities of cayenne pepper.*1wths*.
\end{abstract}

Keywords: distribution channel, Cayenne Chili, Bersehati Market, Manado City

\begin{abstract}
ABSTRAK
Penelitian ini bertujuan untuk mengetahui saluran distribusi cabai rawit di Pasar Bersehati Kota Manado. Data yang digunakan adalah data primer. Data primer diperoleh melalui daftar pertanyaan. Metode pengambilan sampel dengan metode purposive sampling dan Snowball Sampling untuk lembaga pemasaran, sampel diperoleh berdasarkan informasi dari wawancara kepada responden dan ditelusuri ke responden berikutnya dalam rantai. Jumlah responden adalah 20 orang karena mewakili responden. Hasil penelitian ini menunjukkan bahwa Saluran Distribusi yang terjadi di Pasar Bersehati terdiri dari 3 saluran distribusi. Institusi pemasaran yang terlibat termasuk mengumpulkan dealer, pedagang besar, pengecer. Kegiatan distribusi di Pasar Bersehati adalah kegiatan yang dimulai dari mitra dan kerjasama antara petani dan lembaga pemasaran yang terlibat dalam kegiatan pemasaran cabai rawit. *lwths*.
\end{abstract}

Kata kunci: saluran distribusi, komoditi cabai rawit, Pasar Bersehati Kota Manado

\section{PENDAHULUAN}

\section{Latar Belakang}

Hortikultura merupakan Subsektor penting dalam memenuhi kebutuhan pokok manusia. Khususnya tanaman buah dan sayuran merupakan komoditas hortikultura yang berkembang pesat di
Indonesia. Kebanyakan sayuran mempunyai nilai komersial yang cukup tinggi disebabkan produk hortikultura ini senantiasa dikonsumsi setiap saat. Komoditas unggulan nasional hortikultura adalah pisang, mangga, manggis, jeruk, durian, anggrek, rimpang, kentang, bawang merah, dan cabai (Direktorat Jenderal Hortikultura 2008). 
Cabai merupakan salah satu produk hortikultura yang banyak diminati oleh masyarakat karena memiiki kandungan gizi yang bermanfaat bagi kesehatan. Cabai dapat dikonsumsi dalam keadaan mentah ataupun diolah terlebih dahulu sesuai dengan kebutuhan yang akan digunakan. Cabai juga menjadi komoditas agribisnis yang besar pengaruhnya terhadap dinamika perokonomian nasional sehingga dimasukkan dalam jajaran komoditas penyumbang inflasi yang terjadi setiap tahun.

Tanaman cabai dapat dikelompokkan menjadi dua jenis: (1) cabai besar (C. annum) yang terdiri dari cabai merah dan cabai keriting, (2) cabai kecil dikenal dengan nama cabai rawit (Capsicum frustescens, C. pendulum). Bila dibandingkan dengan cabai besar, pembudidayaan cabai rawit relatif lebih mudah karena cabai rawit memiliki keunggulan lebih tahan terhadap serangan hama penyakit serta dapat ditanam di lahan apapun. Cabai rawit digemari untuk dijadikan bahan bumbu masakan karena memiliki rasa yang sangat pedas dibandingkan cabai besar. Selain itu, cabai rawit dapat membuat tampilan masakan menjadi cerah dan mampu meningkatkan selera makan. Kebutuhan akan cabai rawit semakin meningkat seiring dengan meningkatnya jumlah penduduk dan variasi menu masakan.

Cabai rawit memiliki sifat mudah mengalami kerusakan setelah proses pemanenan sehingga masa simpan dari cabai relative singkat, yaitu antara 5 sampai 7 hari. Kerusakan tersebut disebabkan oleh beberapa hal, yaitu pembusukan oleh bakteri atau jamur. Perubahan-perubahan kegiatan enzim didalam cabai itu sendiri yang menyebabkan cabai susut atau keriput, serta penyimpanan dan pengangkutan (Sudaro dan Ratriningsih, 2000).

Pada umumnya, petani cabai rawit tidak menjual langsung hasil produksinya ke pasarpasar di kota besar disebabkan oleh keterbatasan yang dimiliki petani, seperti alat transportasi, pengepakan, dan kegiatan lainnya yang berhubungan dengan pemasaran komoditi tersebut. Selain itu, adanya keterikatan petani kepada pedagang pengumpul dalam permodalan untuk pembelian benih atau bibit, pupuk, pestisida, dan lainnya, yang berjumlah cukup besar. Hal ini mendorong petani untuk menjual hasil produksinya kepada pedagang pengumpul. Sebaliknya, bagi petani yang tidak terikat pinjaman, bebas dalam menentukan pilihan kepada siapa ia akan jual hasil produksinya seperti menjual langsung kepada konsumen pemakai melalui pasar-pasar di tingkat desa atau pasar tingkat kecamatan. Biasanya petani yang demikian mencari pembeli dengan harga tertinggi (Hutabarat dan Rahmanto, 2004).

Menurut Hadiana (2011), 70\% pasokan cabai dikonsumsi untuk kebutuhan rumah tangga dan sisanya digunakan untuk memenuhi kebutuhan industri. Permintaan terhadap cabai rawit untuk kebutuhan sehari-hari dapat berfluktuasi, yang disebabkan karena naik turunnya harga cabai rawit yang terjadi di pasar eceran.

Fluktuasi harga yang terjadi di pasar eceran, selain disebabkan oleh faktor-faktor yang mempengaruhi sisi permintaan juga disebabkan oleh faktor-faktor yang mempengaruhi sisi penawaran. Dari sisi penawaran menunjukkan bahwa proses penyediaan (produksi dan distribusinya) cabai rawit belum sepenuhnya dikuasai para petani. Faktor utama yang menjadi penyebab yaitu bahwa petani cabai rawit adalah petani kecil yang proses pengambilan keputusan produksinya diduga tidak ditangani dan ditunjang dengan suatu peramalan produksi dan harga yang jelas.

Kenaikan harga cabai rawit sangat tergantung pada musim panen dan musim tanam serta pengaruh iklim dan cuaca. Disamping itu, kenaikan harga juga berkaitan dengan kegiatan pemasaran. Bila dibandingkan dengan harga di daerah konsumen, harga cabai rawit di daerah produsen lebih rendah. Pengertian harga menurut Buchari Alma (2004) harga adalah nilai suatu barang atau jasa yang dinyatakan dengan uang.

Bagi masyarakat kota Manado, cabai rawit merupakan salah satu komoditas penting bagi perekonomian pedagang dipasar kota Manado. Dari sisi konsumsi masyarakat Sulawesi Utara, cabai mempunyai pangsa yang cukup signifikan. Melihat kebutuhan masyarakat Manado yang dominan mengkonsumsi cabai rawit maka permintaan akan harga cabai akan tetap terus ada. Di kota Manado sering di temui bahwa harga cabai rawit kadang tinggi dan kadang rendah bahkan cenderung tidak menentu, inilah yang menjadi masalah mengapa hal itu bisa terjadi. Mungkin karena cita rasa dari cabai rawit yang cenderung 
pedas atau karena masyarakat Kota Manado yang memang menyukai cabai rawit atau ada faktor lain yang berpengaruh terhadap harga cabai tersebut.

Dimana, pada hukum permintaan dapat diartikan sebagai hukum yang menjelaskan tentang adanya hubungan yang bersifat negatif antara tingkat harga dengan jumlah barang yang diminta. Apabila harga naik jumlah barang yang diminta sedikit dan apabila harga rendah jumlah barang yang diminta meningkat.

Berdasarkan latar belakang masalah yang diuraikan maka penulis ingin meneliti tentang "bagaimana saluran distribusi komoditi cabai rawit dari tingkat produsen/petani sampai ke Pasar Bersehati di Kota Manado".

\section{Rumusan Masalah}

Berdasakan latar belakang, maka yang menjadi rumusan masalah dalam penelitian ini adalah bagaimana saluran distribusi komoditi cabai rawit dari tingkat produsen/petani sampai ke Pasar Bersehati di Kota Manado.

\section{Tujuan Penelitian}

Penelitian ini bertujuan untuk menginvestigasi saluran distribusi komoditi cabai rawit di Pasar Bersehati Kota Manado.

\section{Manfaat Penelitian}

Manfaat dari penelitian ini untuk menambah informasi bagi konsumen tentang kegiatan distribusi yang terjadi dipasar, dimana Cabai Rawit yang diinginkan dapat sampai ke tangan konsumen.

\section{METODE PENELITIAN}

\section{Waktu dan Tempat Penelitian}

Penelitian ini dilakukan dipasar Bersehati Kota Manado dan menelusuri informasi ke tingkat pelaku-pelaku distribusi sampai ke tingkat petani. Berlangsung selama tiga bulan dengan waktu penelitian dari bulan Februari sampai April 2018 di mulai dari pengumpulan data sampai dengan penyusunan laporan hasil penelitian. Proses pengambilan data dilakukan pada Bulan Maret 2018.

\section{Metode Pengumpulan Data}

Pengumpulan data primer dilakukan dengan cara investigasi dari tingkat pedagang pengecer, pedagang besar, pedagang pengumpul sampai ketingkat petani sebagai produsen untuk mengetahui fluktuatif harga dari hilir ke hulu, melalui wawancara dan isian kuisioner dipasar Bersehati Kota Manado dan menelusuri distribusi sampai ke tingkat petani sebagai produsen awal.

\section{Metode Pengambilan Sampel}

Metode pengambilan sampel dalam penelitian ini dilakukan secara Purposive Sampling (secara sengaja) yaitu memilih pedagang cabai dipasar Bersehati, kemudian menelusuri dari mana di dapatkan produk cabai, dan informasi didapatkan dengan teknik efek Bola Salju "Snowball" Dari hilir ke hulu. Jumlah keseluruhan responden yang digunakan dalam penelitian ini sebanyak 20 responden yang terdiri dari 10 Pedagang Pengecer, 8 Pedagang Besar, dan 2 Pedagang Pengumpul.

\section{Pengukuran Variabel Penelitian}

Adapun variabel-variabel yang diukur dalam penelitian saluran distribusi ini adalah sebagai berikut:

a. Pedagang Pengecer

Pedagang yang berhubungan langsung dengan konsumen akhir dan memperoleh pasokan cabai dari para pedagang besar dengan jumlah pembelian lebih dari lima kilogram.

b. Pedagang Besar

Pedagang yang membeli cabai rawit dari pedagang pengumpul dalam jumlah besar untuk dijual kembali kepada para pengecer atau kepada perusahaan-perusahaan industri.

c. Pedagang Pengumpul

Pedagang yang mengumpulkan/membeli dari petani, hasil pertanian cabai rawit untuk kemudian menjualnya kembali kepada pedagang besar dan badan usaha industri yang bergerak dalam sektor tersebut.

d. Petani

Seseorang(produsen) yang bergerak di bidang pertanian/memproduksi, yang bertujuan untuk memelihara tanaman dengan harapan untuk memperoleh hasil dari tanaman tersebut untuk menjualnya kepada orang lain/pedagang.

Variabel-variabel yang diukur dalam Penelitian:

1. Harga cabai rawit yang dijual per $\mathrm{kg}$

2. Volume cabai rawit yang terjual perhari $(\mathrm{kg})$ 
3. Volume cabai rawit yang dibeli dari pedagang sebelumnya $(\mathrm{kg})$

4. Harga per $\mathrm{kg}$ cabai rawit yang dibeli dari pedagang sebelumnya

5. Kegiatan-kegiatan yang dibutuhkan dalam proses penjualan cabai rawit

6. Asal daerah cabai rawit itu didapatkan

7. Saluran distribusi cabai rawit yang tejadi di pasar bersehatai kota manado.

\section{Analisis Data}

Data yang dikumpulkan melalui kuisioner dan wawancara, ditabulasikan dan dianalisis selanjutnya dideskripsikan untuk menjawab tujuan penelitian. Untuk mengetahuti selisih harga dari masing-masing lembaga pemasaran yang terlibat dalam distribusi komoditi cabai, digunakan analisis kualitatif.

\section{HASIL DAN PEMBAHASAN}

\section{Deskripsi Daerah Penelitian Pasar Bersehati}

\section{Letak Geografis dan Luas Wilayah Pasar Bersehati}

Pasar Bersehati adalah salah satu pusat perbelanjaan yang ada di Kota Manado, yang Posisinya terletak sangat strategis. Terletak bersebelahan dengan pelabuhan Manado, yang bagian atasnya dilewati jembatan Soekarno. Lokasi dari Pasar Tradisional Bersehati ini terletak Jl. Nusantara, Kelurahan Calaca, Kecamatan Wenang, Kota Manado.Secara Geografis letak Kota Manado berada pada $1^{\circ} 30^{\prime}$ $1[\mathrm{~B} 1]^{\circ} \quad 40^{\prime}$ Lintang Utara dan $124^{\circ} 40^{\prime}$ 126[B2] ${ }^{\circ} 50^{\prime}$ Bujur Timur.Adapun batas-batas dari Kecamatan Wenang yaitu :

- Sebelah Utara : Sungai Jengki dan Kecamatan Singkil

- Sebelah Timur : Kecamatan Tikala

- Sebelah Selatan : Kecamatan Sario dan Kecamatan Wanea

- Sebelah Barat : Teluk Manado Jam 03.00 subuh, saat matahari pagi belum bersinar di langit kota Manado, pasar Bersehati mulai berdenyut mengawali aktivitasnya. Dibalik remang-remang gelap subuh, kendaraan pick up, motor dan gerobak keluar masuk mengangkut hasil bumi. Ikan, sayursayuran, rempah-rempah dan buah-buahan berdatangan dari berbagai pelosok Minahasa. Para pedagang sibuk mengatur dan menata berbagai jenis barang dagangannya untuk menyambut datangnya pembeli di pagi hari.

Pasar Bersehati dibangun tahun 1973. Keberadaannya memiliki tempat tersendiri di hati masyarakat. Merupakan pasar tradisional terbesar, baik dari jumlah pedagang, kios dan los maupun dari jumlah orang yang datang berbelanja. Mereka mencari nafkah dan menggantungkan hidupnya dari keberadaan pasar tradisonal yang memiliki luas $5 \mathrm{Ha}$ ini. Juga terdapat warung kopi dan makanan, khususnya yang menjual makanan khas Manado seperti tinutuan, mie cakalang, pisang goreng dan berbagai jenis makanan dari daerah lainnya di nusantara.

Jenis barang dagangan yang dijual di pasar Bersehati adalah barang-barang kebutuhan seharihari, mulai dari beras, gula, tepung dan jenis sembako lainnya. Bahan sembako tersebut ada yang dijual secara grosir. Barang dagangan lainnya seperti sayur, ikan dan daging biasanya dijual di lokasi sesuai namanya. Barang dagangan seperti rica (cabe), tomat, bawang, jeruk dan rampah-rampah campur, adalah bahan penyedap rasa dan penambah selera yang banyak dicari oleh ibu-ibu rumah tangga.Buah-buahan seperti pisang, kelapa muda, salak, mangga, nangka, dan jenis buah-buahan lainnya dijual di lokasi khusus, yang diberi nama Pasar Buah.

Lokasinya adalah eks kuala Jengki yang direklamasi/ ditimbun oleh pemerintah.Selain menjual beraneka ragam barang dan bahan makanan, pasar Bersehati juga menjual baju-baju, tas, sepatu, accesories dan peralatan lainnya yang dibutuhkan masyarakat golongan ekonomi menengah ke bawah. Bersehati merupakan akronim dari kata Bersih, Sehat, Aman, Tetib dan Indah. Kata Bersehati digunakan sebagai nama pasar sekitar tahun 1985 pada masa WaManado, Ir. Nayoan Habel Eman (1985-1995).

\section{Karakteristik Responden Saluran Distribusi Cabai Rawit}

\section{Jenis Kelamin Responden}

Dalam penelitian ini jenis kelamin sangat berpengaruh dalam proses saluran untuk Distribusi cabai rawit, sebagian besar laki-laki adalah yang sangat berperan dalam proses Penyaluran di pasar, karena laki-laki tidak mengenal lelah atau tidak sungkan-sungkan dalam mengangkat/memindahkan cabai rawit tersebut. 


\begin{tabular}{cccr} 
Tabel 1. Jenis Kelamin & & \\
\hline No & Jenis kelamin & Jumlah Responden & Persentase (\%) \\
\hline 1 & Laki-laki & 14 & 70 \\
2 & Perempuan & 6 & 30 \\
\hline \multicolumn{6}{c}{ Jumlah } & $\mathbf{2 0}$ & $\mathbf{1 0 0}$ \\
\hline
\end{tabular}

Sumber: Diolah dari Data Primer (2018)

Tabel 1 Menunjukkan bahwa, jumlah responden laki-laki sebanyak 14 responden (70\%) dan responden perempuan berjumlah $6(30 \%)$.

\section{Umur Responden}

Umur seseorang sangat berpengaruh terhadap kemampuan seseorang untuk bekerja secara fisk maupun cara berpikirnya, semakin tinggi umur pedagang semakin berkurang kemampuan dalam bekerja juga cara berpikirnya, sedangkan pedagang yang berumur muda pada umumnya mempunyai kemampuan fisik yang lebih baik dan cara berpikir yang masih detail. Menurut hasil penelitian umur pedagang responden dapat dilihat pada Tabel 2.

Tabel 2. Umur Responden Pedagang Pengecer

\begin{tabular}{cccr}
\hline No & Umur (Tahun) & Jumlah Responden & Persentase (\%) \\
\hline 1 & $20-30$ & 2 & 20 \\
2 & $31-40$ & 5 & 50 \\
3 & $41-50$ & 2 & 20 \\
4 & $51-60$ & 1 & 10 \\
\hline & Jumlah & $\mathbf{1 0}$ & $\mathbf{1 0 0}$ \\
\hline
\end{tabular}

Sumber: Data Primer di olah(2018)

Tabel 2 menunjukkan jumlah responden pada umur anggota pedagang. Umur 20-30 tahun yaitu sebanyak 2 responden (20\%), pada umur 3140 tahun menunjukkan Persentase yaitu sebanyak 5 responden (50\%), umur 41-50 tahun sebanyak 2 responden $(20 \%)$ selanjutnya berada pada umur 51-60 tahun menunjukkan Persentase sebanyak 1 responden (10\%).

Tabel 3. Umur Responden Pedagang Besar

\begin{tabular}{cccr}
\hline No & Umur (Tahun) & Jumlah Responden & Persentase (\%) \\
\hline 1 & $20-30$ & 3 & 37,5 \\
2 & $31-40$ & - & - \\
3 & $41-50$ & 4 & 50 \\
4 & $51-60$ & 1 & 12,5 \\
\hline \multicolumn{4}{r}{ Sumber: Diolah dari Data Primer (2018) }
\end{tabular}

Tabel 3 menunjukkan jumlah responden pada umur anggota pedagang. Umur 20-30 tahun yaitu sebanyak 3 responden (37,5\%), pada umur 31-40 tahun menunjukkan Persentase yaitu sebanyak 0 responden (0\%), umur 41-50 tahun sebanyak 4 responden (50\%) selanjutnya berada pada umur 51-60 tahun menunjukkan Persentase sebanyak 1 responden $(12,5 \%)$.
Tabel 4. Umur Responden Pedagang Pengumpul

\begin{tabular}{|c|c|c|c|}
\hline No & Umur (Tahun) & Jumlah Responden & Persentase (\%) \\
\hline 1 & $20-40$ & 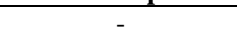 & \\
\hline 2 & $41-60$ & 2 & 100 \\
\hline & Jumlah & 2 & 100 \\
\hline
\end{tabular}

Tabel 4 menunjukkan jumlah responden pada umur anggota pedagang. Umur 20-40 tahun yaitu sebanyak 0 responden $(0 \%)$, pada umur 41-60 tahun menunjukkan Persentase yaitu sebanyak 2 responden (100\%).

\section{Tingkat Pendidikan Responden}

Peranan pendidikan formal sangat penting dalam usaha meningkatakan kualitas seseorang karena berguna dalam pembangunan pribadi serta peningkatan intektual dan wawasan seseorang. Berdasarkan hasil penelitian, tingkat pendidikan responden bervariasi mulai dari tingkat Sekoah Dasar (SD), SLTP/SMP, SMA, dan S1. Komposisi tingkat pendidikan responden dalam penelitian ini dapat dilihat pada Tabel 5.

Tabel 5. Tingkat pendidikan responden Pedagang Pengecer

\begin{tabular}{cccr}
\hline No & Umur (Tahun) & Jumlah Responden & Persentase (\%) \\
\hline 1 & SD & 4 & 40 \\
2 & SMP & 1 & 10 \\
3 & SMA & 5 & 50 \\
4 & S1 & - & - \\
\hline & Jumlah & $\mathbf{1 0}$ & $\mathbf{1 0 0}$ \\
\hline
\end{tabular}

Sumber: Diolah dari Data Primer (2018)

Tabel 5 menunjukkan responden menurut tingkat pendidikan anggota pedagang pasar. Tingkat pendidikan SD berjumlah 4 responden (40\%), SLTP/SMP berjumlah 1 responden (10\%), SMA/SMK berjumlah 5 responden $(50 \%)$, dan sarjana berjumlah 0 responden $(0 \%)$.

\begin{tabular}{clcr}
\multicolumn{6}{c}{ Tabel 6. Tigkat Pendidikan Responden Pedagang Besar } \\
\hline No & Jmur (Tahun) & Jumlah Responden & Persentase (\%) \\
\hline 1 & SD & 4 & 50 \\
2 & SMP & 3 & 37,5 \\
3 & SMA & 1 & 12,5 \\
4 & S1 & - & - \\
\hline \multicolumn{7}{l}{ Jumlah } & $\mathbf{8}$ & $\mathbf{1 0 0}$ \\
\hline
\end{tabular}

Tabel 6 menunjukkan responden menurut tingkat pendidikan anggota pedagang pasar. Tingkat pendidikan SD berjumlah 4 responden (50\%), SLTP/SMP berjumlah 3 responden $(37,5 \%)$, SMA/SMK berjumlah 1 responden $(12,5 \%)$, dan sarjana berjumlah 0 responden $(0 \%)$. 
Tabel 7. Tingkat Pendidikan Responden Pedagang Pengumpul

\begin{tabular}{cccr}
\hline No & Umur (Tahun) & Jumlah Responden & Persentase (\%) \\
\hline 1 & SD & - & - \\
2 & SMP & 1 & 50 \\
3 & SMA & 1 & 50 \\
4 & S1 & - & - \\
\hline & Jumlah & $\mathbf{2}$ & $\mathbf{1 0 0}$ \\
\hline
\end{tabular}

Sumber: Diolah dari Data Primer (2018)

Tabel 7 menunjukkan responden menurut tingkat pendidikan anggota pedagang pasar. Tingkat pendidikan SD berjumlah 0 responden (0\%), SLTP/SMP berjumlah 1 responden $(50 \%)$, SMA/SMK berjumlah 1 responden $(50 \%)$, dan sarjana berjumlah 0 responden $(0 \%)$.

\section{Pengalaman Berdagang}

Pengalaman berdagang dapat mempengaruhi cara dan keahlian berdagang cabai rawit, Misalnya menentukan volume penjualan, Kerjasama antar petani dan pedagang serta kecepatan memperoleh informasi pasar. Lamanya pengalaman berdagang pedagang cabai rawit dapat dilihat pada Tabel 8 .

\begin{tabular}{cccr}
\multicolumn{6}{l}{ Tabel 8. Pengalaman Pedagang Pengecer } & \\
\hline No & Tahun & Jumlah Responden & Persentase (\%) \\
\hline 1 & $1-10$ & 8 & 80 \\
2 & $11-20$ & 2 & 20 \\
3 & $21-30$ & - & - \\
4 & $31-40$ & - & - \\
\hline & Jumlah & $\mathbf{1 0}$ & $\mathbf{1 0 0}$ \\
\hline Sumber:
\end{tabular}

Tabel 8 menunjukkan responden menurut pengalaman berdagang anggota pedagang pasar. Lamanya berdagang dari 1-10 tahun berjumlah 8 responden $(80 \%), 11-20$ tahun berjumlah 2 responden (20\%), 21-30 tahun berjumlah 0 responden (0\%), dan 31-40 tahun berjumlah 0 responden $(0 \%)$.

\begin{tabular}{|c|c|c|c|}
\hline No & Tahun & Jumlah Responden & Persentase (\%) \\
\hline 1 & $1-10$ & 3 & 37,5 \\
\hline 2 & $11-20$ & 1 & 12,5 \\
\hline 3 & $21-30$ & 2 & 25 \\
\hline \multirow[t]{2}{*}{4} & $31-40$ & 2 & 25 \\
\hline & Jumlah & 8 & 100 \\
\hline
\end{tabular}

Sumber: Diolah dari Data Primer (2018)

Tabel 9 menunjukkan responden menurut pengalaman berdagang anggota pedagang pasar. Lamanya berdagang dari 1-10 tahun berjumlah 3 responden $(37,5 \%), 11-20$ tahun berjumlah 1 responden $(12,5 \%), 21-30$ tahun berjumlah 2 responden (25\%), dan 31-40 tahun berjumlah 2 responden $(25 \%)$.
Tabel 10. Pengalaman Pedagang Pengumpul

\begin{tabular}{cccr}
\hline No & Tahun & Jumlah Responden & Persentase (\%) \\
\hline 1 & $1-10$ & - & - \\
2 & $11-20$ & 1 & 50 \\
3 & $21-30$ & 1 & 50 \\
4 & $31-40$ & - & - \\
\hline & Jumlah & $\mathbf{2}$ & $\mathbf{1 0 0}$ \\
\hline
\end{tabular}

Sumber: Diolah dari Data Primer (2018)

Tabel 10 menunjukkan responden menurut pengalaman berdagang anggota pedagang pasar. Lamanya berdagang dari 1-10 tahun berjumlah 0 responden $(0 \%), 11-20$ tahun berjumlah 1 responden (50\%), 21-30 tahun berjumlah 1 responden (50\%), dan 31-40 tahun berjumlah 0 responden $(0 \%)$.

\section{Distribusi Cabai Rawit di Pasar Bersehati Manado}

Distribusi cabai rawit merupakan kegiatan penyampaian komoditi cabai rawit dari petani hingga sampai ke konsumen dengan tujuan mendapatkan nilai uang sebagai balas jasa atas hasil komoditinya. Proses distribusi dilakukan petani setelah melalui panen selama satu hari atau lebih tergantung keadaan cuaca. Sistem penjualan yang terjadi pada komoditi cabai rawit di pasar bersehati ada tiga sistem yaitu pertama, secara langsung produsen (petani) langsung memasarkan kepada pedagang besar yang ada di pasar. Kedua melalui perantara yaitu pedagang pengumpul kemudian menjualnya kepada pedagang besar yang ada di pasar Bersehati, kemudian pedagang besar menjual cabai rawit di pasar tersebut. Ketiga pedagang pengecer membeli cabai rawit dari pedagang besar, kemudian menjualnya langsung ke konsumen.

\section{Lembaga Distribusi Cabai Rawit}

Sistem saluran distribusi cabai rawit di pasar bersehati tidak lepas dari peran lembagalembaga pemasaran yang mengambil bagian dalam kegiatan dsitribusi. Lembaga saluran distribusi terdiri atas petani, pedagang pengumpul desa, pedagang besar, pedagang pengecer dan konsumen. Masing-masing lembaga distribusi mempunyai peranan penting dalam pemasaran cabai rawit.

1. Petani

Petani merupakan produsen cabai rawit yang mengawali saluran distribusi cabai rawit di pasar Bersehati Manado. 
2. Pedagang pengumpul

Pedagang yang melakukan aktivitas membeli cabai rawit dari petani untuk kemudian dijual kepada pedagang besar di pasar. Pedagang pengumpul melakukan kesepakatan kepada pedagang besar seperti penetapan jumlah cabai rawit yang diminta, harga jual serta sistem pembayaran kepada para pedagang besar, pemesanan dilakukan melalui telepon selular. Hasil penelitian mengambil sampel sebanyak dua pedagang pengumpul yang berada diPasar Bersehati Manado.

3. Pedagang Besar

Pedagang yang membeli cabai rawit dari pedagang pengumpul kemudian menjualnya dipasar. Hasil penelitian mengambil sempel sebanyak delapan pedagang besar yang berjualan dipasar bersehati Manado.

4. Pedagang Pengecer

Pedagang yang melakukan transaksi pembelian dari pedagang besar dan kemudian menjualnya langsung kepada konsumen tanpa perantara. Hasil penelitian mengambil sempel sebanyak 11 pedagang pengecer yang berjualan dipasar Bersehati Manado.

5. Konsumen

Orang yang membeli langsung cabai rawit dari pedagang pengecer dan juga dari pedagang besar yang ada diPasar untuk dikonsumsi.

\section{Kegiatan Pedagang dalam Proses Distribusi Cabai Rawit}

Lembaga-lembaga yang terlibat dalam distribusi cabai rawit, masing-masing menjalankan fungsi-fungsi distribusi dimana setiap lembaga memiliki fungsi yang berbedabeda. Fungsi distribusi bertujuan untuk memperlancar penyaluran cabai rawit petani dari petani ke konsumen.

\section{Kegiatan Pedagang Pengecer}

Adapun kegiatan-kegiatan yang dilakukan oleh pedagang pengecer antara lain:

1. Sortir Yaitu memilih (yang diperlukan dan mengeluarkan yang tidak diperlukan) atau dengan arti lain yaitu kegiatan yang dilakukan dalam memilih-milih/memilah cabai rawit.
2. Retribusi Yaitu Pungutan daerah sebagai pembeyaran atas jasa atau pemberian ijin tertentu untuk kepentingan pribadi atau badan usaha.

3. Sewa tempat Yaitu Sebuah persetujuan dimana sebuah pembayaran dilakukan atas penggunaan suatu tempat secara sementara oleh orang lain.

\section{Kegiatan Pedagang Besar}

Adapun kegiatan-kegiatan yang dilakukan oleh pedagang besar antara lain :

1. Penyimpanan Yaitu Mengelolah cabai rawit yang ada dalam persediaan, dengan maksud selalu dapat menjamin ketersediaannya.

2. Sortir Yaitu Memilih (yang diperlukan dan mengeluarkan yang tidak diperlukan) atau dengan arti lain yaitu kegiatan yang dilakukan dalam memilih-milih/memilah cabai rawit.

3. Tenaga kerja Yaitu Seseorang yang mampu melakukan suatu pekerjaan guna menghasilkan cabai rawit untuk memenuhi kebutuhan sendiri atau masyarakat sekitar.

4. Sewa tempat Yaitu Sebuah persetujuan dimana sebuah pembayaran dilakukan atas penggunaan suatu tempat secara sementara oleh orang lain.

\section{Kegiatan Pedagang Pengumpul}

Adapun kegiatan-kegiatan yang dilakukan oleh pedagang pengumpul antara lain:

1. Pengangkutan Yaitu Perjanjian timbal balik antara pengangkut dengan pengirim, dimana pengangkut mengikatkan diri untuk menyelenggarakan pengangkutan cabai rawit dari suatu tempat ketempat tujuan.

2. Tenaga kerja Yaitu Seseorang yang mampu melakukan suatu pekerjaan guna menghasilkan cabai rawit untuk memenuhi kebutuhan sendiri atau masyarakat sekitar.

3. Penyimpanan Yaitu Mengelolah cabai rawit yang ada dalam persediaan, dengan maksud selalu dapat menjamin ketersediaannya.

4. Retribusi Yaitu Pungutan daerah sebagai pembeyaran atas jasa atau pemberian ijin tertentu untuk kepentingan pribadi atau badan usaha.

5. Sortir Yaitu Memilih (yang diperlukan dan mengeluarkan yang tidak diperlukan) atau dengan arti lain yaitu kegiatan yang dilakukan dalam memilih-milih/memilah cabai rawit. 


\section{Saluran Distribusi Cabai Rawit di Pasar Bersehati Manado}

Saluran distribusi merupakan kegiatan yang berfungsi untuk memperlancar arus barang dari produsen (petani) hingga sampai ke konsumen secara efisien melalui rangkaian rangkaian lembaga distribusi. Penyaluran hasil produksi dari petani hingga sampai ke konsumen melalui lebih dari satu saluran distribusi, dimana masing-masing saluran melibatkan lembaga distribusi yang berbeda. Hasil penelitian menunjukkan ada tiga saluran distribusi diPasar Bersehati Manado yaitu:

1. Saluran distribusi I (Gorontalo dan Palu)

Pada saluran I ini, petani menjual cabai rawit kepada pedagang pengumpul desa. Hal ini dilakukan karena pedagang pengumpul langsung datang kerumah dan ke lahan petani untuk membeli cabai rawit setelah itu dijual kepada pedagang besar, kemudian ke pedagang pengecer yang ada di Pasar Bersehati Manado yang berhadapan langsung dengan konsumen akhir. Pedagang pengumpul desa biasanya mensortir cabai rawit yang telah mereka beli dari petani sebelum menjualnya kepada pihak pedagang besar di Pasar. Dalam hal ini pedagang pengumpul sifatnya kekeluargaan dengan petani sehingga harga yang ditawarkan masih rendah. Saluran distribusi I dapat dilihat pada gambar 1.

\section{pengecer $\rightarrow$ Pedagang besar $\rightarrow$ Pedagang pengumpul $\rightarrow$ Petani}

Gambar 1. Saluran distribusi I

2. Saluran distribusi II ( Kotamobagu)

Pada saluran II ini, petani cabai rawit menjual langsung hasil panen ke pedagang besar kemudian pedagang besar menjual langsung ke pedagang pengecer di Pasar Bersehati. Pedagang besar di Pasar Bersehati juga melakukan kegiatan penyortiran cabai rawit yang telah mereka beli dari pedagang pengumpul desa. Dalam hal ini pedagang besar membeli berapapun jumlah cabai rawit yang dijual oleh petani dengan penentuan harga negosiasi. Saluran distribusi II dapat dilihat pada gambar 2 .

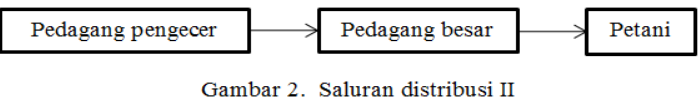

3. Saluran distribusi III (MINUT)

Pada saluran III ini, petani menjual cabai rawit ke pedagang besar kemudian menjual langsung ke konsumen. Dalam hal ini, konsumen membeli langsung cabai rawit ke pedagang besar untuk menghemat biaya.

Pada saluran distribusi cabai rawit yang terjadi dipasar bersehati yaitu mengunakan Distribusi Eksklusif. Distribusi ini sangat membatasi jumlah perantara dan digunakan apabila produsen ingin tetap memegang kendali atas tingkat dan keluaran layanan yang ditawarkan perantara tersebut. Dengan memberikan distribusi eksklusif, produsen tersebut berharap untuk memperoleh penjualan yang lebih berdedikasi dan lebih mengenal produk tersebut.

Responden yang paling menentukan fluktuasi harga yang terjadi di pasar bersehati yaitu pedagang besar. Dikarenakan pedagang besar dapat mengontrol harga yang terjadi di pasar dan juga pada pedagang sebelumnya yaitu pedagang pengumpul. Saluran distribusi III dapat dilihat pada gambar 3.

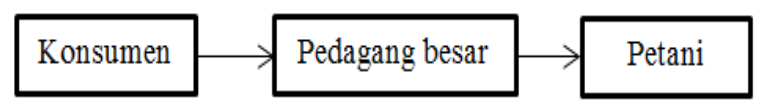

Gambar 3. Saluran distribusi III (Petani dari MINUT)

\section{Asal Daerah Cabai Rawit di Pasar Bersehati Manado}

Cabai rawit merupakan tanaman hortikultura tanaman hortikultura (sayuran) yang buahnya dimanfaatkan untuk keperluan aneka pangan. Cabai rawit banyak digunakan sebagai bumbu dapur, yakni sebagai bahan penyedap berbagai macam masakan antara lain sambal, saus, aneka sayur, acar, lalap, asinan, dan produk-produk makanan kaleng. Adapun asal daerah cabai rawit yang dijual dipasar Bersehati Manado antara lain yaitu:
1. Cabai rawit gorontalo
2. Cabai rawit palu
3. Cabai rawit kotamobagu
4. Cabai rawit minut 


\section{Harga Menurut Jenis Cabai Rawit Ditiap Responden}

Tabel 11 menunjukkan bahwa terdapat perbedaan harga cabai ditiap responden. Harga cabai rawit Gorontalo pada pedagang pengecer sebesar Rp 45.000 dengan margin sebesar Rp.5.000, pedagang besar Rp 40.000 dengan margin sebesar Rp.5.000, pedagang pengumpul Rp 35.000 dengan margin sebesar Rp.5.000, dan Petani menjualnya sebesar Rp. 30.000 .

\begin{tabular}{llrr}
\multicolumn{4}{c}{ Tabel 11. Harga Cabai Rawit Gorontalo (kg) } \\
\hline No & Pedagang & Jumlah harga (Rp) & Margin harga(Rp) \\
\hline 1 & Pengecer & 45.000 & 5.000 \\
2 & Besar & 40.000 & 5.000 \\
3 & Pengumpul & 35.000 & 5.000 \\
4 & Petani & 30.000 & - \\
\hline \multicolumn{4}{l}{ Sumber: Diolah dari Data Primer (2018) }
\end{tabular}

Tabel 12 menunjukkan bahwa terdapat perbedaan harga cabai ditiap responden. Harga cabai rawit Palu pada pedagang pengecer sebesar Rp 42.000 dengan margin sebesar Rp. 4.000, pedagang besar Rp 38.000 dengan margin sebesar Rp. 3.000, pedagang pengumpul Rp 35.000 dengan margin sebesar Rp. 5.000, dan Petani sebesar Rp. 30.000.

Tabel 12. Harga Cabai Rawit Palu (kg)

\begin{tabular}{clrr}
\hline No & Pedagang & Jumlah harga (Rp) & Margin harga (Rp) \\
\hline 1 & Pengecer & 42.000 & 4.000 \\
2 & Besar & 38.000 & 3.000 \\
3 & Pengumpul & 35.000 & 5.000 \\
4 & Petani & 30.000 & - \\
\hline \multicolumn{2}{l}{ Sumber: Diolah dari Data Primer $(2018)$}
\end{tabular}

Tabel 13 menunjukkan perbedaan harga cabai rawit ditiap responden. Harga cabai rawit Kotamobagu pada pedagang pengecer sebesar Rp 40.000 dengan margin sebesar Rp. 5.000, pedagang besar $\mathrm{Rp} 35.000$ dengan margin sebesar Rp. 5.000, pedagang pengumpul Rp 30.000 dengan margin sebesar R5.000, dan Petani sebesar Rp. 25.000.

Tabel 13. Harga Cabai Rawit Kotamobagu (kg)

\begin{tabular}{clrr}
\hline No & Pedagang & Jumlah harga (Rp) & Margin harga (Rp) \\
\hline 1 & Pengecer & 40.000 & 5.000 \\
2 & Besar & 35.000 & 5.000 \\
3 & Pengumpul & 30.000 & 5.000 \\
4 & Petani & 25.000 & - \\
\hline \multicolumn{4}{l}{ Sumber: Diolah dari Data Primer (2018) }
\end{tabular}

Tabel 14 menunjukkan perbedaan harga cabai rawit ditiap responden. Harga cabai rawit MINUT pada pedagang pengecer sebesar $\mathrm{Rp}$ 38.000 dengan margin sebesar $\mathrm{Rp} 3.000$, pedagang besar Rp 35.000 dengan margin sebesar Rp. 3.000, pedagang pengumpul Rp 32.000 dengan margin sebesar Rp. 4.000, dan Petani sebesar Rp. 28.000.

Tabel 14. Harga Cabai Rawit Minut (kg)

\begin{tabular}{clrr}
\hline No & Pedagang & Jumlah harga(Rp) & Margin harga (Rp) \\
\hline 1 & Pengecer & 38.000 & 3.000 \\
2 & Besar & 35.000 & 3.000 \\
3 & Pengumpul & 32.000 & 4.000 \\
4 & Petani & 28.000 & - \\
\hline \multicolumn{2}{l}{ Sumber: data primer diolah (2018) }
\end{tabular}

\section{Jumlah (kg) Yang Dijual Oleh Setiap Pedagang}

Tabel 15 menunjukkan rata-rata jumlah cabai rawit yang terjual perhari oleh pedagang pengecer dalam setiap kilogram yaitu sebanyak $30,5 \mathrm{~kg}$ per hari dan rata-rata harga jual cabai rawit yaitu sebesar Rp. 45.200.

Keterangan asal cabai rawit: $\mathrm{CG}=\mathrm{Cabai}$ Gorontalo, $\mathrm{CP}=$ Cabai Palu, $\mathrm{CK}=$ Cabai

Kotamobagu.

Tabel 15. Jumlah Cabai Rawit dan Harga Jual Pedagang Pengecer di Pasar Bersehati Manado (perhari)

\begin{tabular}{crr}
\hline Pengecer & Jumlah yang dijual $(\mathbf{K g})$ & Harga Jual $(\mathbf{R p} / \mathbf{K g})$ \\
\hline 1 & $50(\mathrm{cg})$ & 45.000 \\
2 & $40(\mathrm{cg})$ & 50.000 \\
3 & $40(\mathrm{cg})$ & 40.000 \\
4 & $45(\mathrm{cg})$ & 42.000 \\
5 & $15(\mathrm{cp})$ & 45.000 \\
6 & $20(\mathrm{ck})$ & 40.000 \\
7 & $25(\mathrm{cp})$ & 45.000 \\
8 & $20(\mathrm{cp})$ & 50.000 \\
9 & $20(\mathrm{ck})$ & 45.000 \\
10 & $30(\mathrm{cp})$ & 50.000 \\
\hline Total & $\mathbf{3 0 5}$ & $\mathbf{4 5 2 . 0 0 0}$ \\
\hline Rata- & & \\
Rata & $\mathbf{3 0 , 5}$ & $\mathbf{4 5 . 2 0 0}$ \\
\hline Sumber: Data Primer diolah(2018)
\end{tabular}

Tabel 16 menunjukkan rata-rata jumlah cabai rawit yang terjual perhari oleh pedagang besar dalam setiap kilogram yaitu sebanyak 775 $\mathrm{kg}$ per hari dan rata-rata harga jual cabai rawit yaitu sebesar Rp 35.375.

Keterangan asal cabai rawit: $\mathrm{CG}=$ Cabai Gorontalo, $\mathrm{CP}=$ Cabai Palu, $\mathrm{CK}=$ Cabai Kotamobagu.

Tabel 17 menunjukkan rata-rata jumlah cabai rawit yang terjual perhari oleh pedagang pengumpul dalam setiap kilogram yaitu sebanyak 
$3500 \mathrm{~kg}$ per hari dan rata-rata harga jual cabai rawit yaitu sebesar $\mathrm{Rp} 30.000$.

Keterangan asal cabai rawit: $\mathrm{CG}=$ Cabai Gorontalo, $\mathrm{CP}=$ Cabai Palu, $\mathrm{CK}=$ Cabai Kotamobagu.

\begin{tabular}{ccr} 
Tabel 17. & $\begin{array}{c}\text { Jumlah Cabai Rawit dan Harga Jual } \\
\text { Pedagang Pengumpul di Pasar Bersehati } \\
\text { Manado }\end{array}$ \\
\hline Pengumpul & $\begin{array}{c}\text { Jumlah yang } \\
\text { dijual }(\text { Kg) }\end{array}$ & $\begin{array}{r}\text { Harga Jual } \\
\text { (Rp/Kg) }\end{array}$ \\
\hline 1 & $5000(\mathrm{cg})$ & 30.000 \\
2 & $2000(\mathrm{cp}, \mathrm{ck})$ & 30.000 \\
\hline Total & $\mathbf{7 0 0 0}$ & $\mathbf{6 0 . 0 0 0}$ \\
\hline Rata-Rata & $\mathbf{3 5 0 0}$ & $\mathbf{3 0 . 0 0 0}$ \\
\hline Sumber: data diolah $(2018)$ &
\end{tabular}

\section{KESIMPULAN DAN SARAN}

\section{Kesimpulan}

Berdasarkan hasil penelitian yang telah dilakukan di Pasar Bersehati Manado mengenai distribusi cabai rawit disimpulkan bahwa:

Terdapat tiga saluran distribusi yang terjadi di Pasar Bersehati Manado yaitu:

Saluran distribusi pertama terjadi dari Pengecer $\longrightarrow$ Pedagang Besar $\longrightarrow$ Pedagang Pengumpul $\longrightarrow$ Petani

Saluran distribusi kedua terjadi dari Pengecer $\longrightarrow$ Pedagang Besar $\longrightarrow$ Petani

Saluran distribusi ketiga yaitu dari Konsumen

$\longrightarrow$ Pedagang Besar $\longrightarrow$ Petani

Perilaku pasar yang terjadi di tingkat petani jika dilihat dari praktik penjualan langsung dengan menggunakan sistem pembayaran tunai. Adapun asal cabai rawit yang terdapat dipasar bersehati yaitu: Cabai Rawit dari Gorontalo, Palu, Kotamobagu, dan Cabai Rawit dari Minut.

Adapun asal daerah Pedagang Pengecer dari Gorontalo yaitu sebanyak 6 Responden, dan Manado sebanyak 4 Responden. Pedagang Besar dari Gorontalo Yaitu sebanyak 6 Responden, dan Manado sebanyak 2 Responden. Pedagang Pengumpul dari Gorontalo Yaitu sebanyak 1 responden, dan Manado sebanyak 1 Responden.

Pada saluran distribusi cabai rawit yang terjadi dipasar bersehati yaitu mengunakan Distribusi Eksklusif. Distribusi ini sangat membatasi jumlah perantara dan digunakan apabila produsen ingin tetap memegang kendali atas tingkat dan keluaran layanan yang ditawarkan perantara tersebut. Dengan memberikan distribusi eksklusif, produsen tersebut berharap untuk memperoleh penjualan yang lebih berdedikasi dan lebih mengenal produk tersebut.

\section{Saran}

Berdasarkan hasil penelitian maka dapat disarankan bahwa Perlu diperhatikan dengan baik Saluran distribusi cabai rawit yang terjadi dipasar bersehati di kota Manado. Dan juga perlu adanya pasar induk untuk mengontrol harga dipasar agar responden yang terlibat dalam saluran dapat mengetahui harga cabai rawit yang sebenarnya terjadi.

Penulis menyadari bahwa penelitian ini masih belum bias dikatakan sempurna, untuk itu penulis berharap agar dilakukan penelitian lanjut tentang harga cabai.

\section{DAFTAR PUSTAKA}

Buchari Alma, 2004, Manajemen Pemasaran dan Pemasaran Jasa, Alfabeta, Bandung.

Direktorat Jenderal Hortikultura. 2008. Membangun Hortikultura Berdasarkan Enam Pilar Pengembangan.

Hutabarat B, Rahmanto B. 2004. Dimensi oligopsonistik pasar domestik cabai rawit. Jurnal Sosial Ekonomi Pertanian dan Agribisnis. SOCA. Fakultas Pertanian Universitas Udayana. Denpasar.

Sudaro, Y. dan Ratriningsih, AD, 2000 . Pengeringan Cabai . PT. Penebar Swadaya. Jakarta . 